\title{
The laminin $\beta 1$-competing peptide YIGSR induces a hypercontractile, hypoproliferative airway smooth muscle phenotype in an animal model of allergic asthma
}

\author{
Bart GJ Dekkers ${ }^{1 *}$, I Sophie T Bos ${ }^{1}$, Andrew J Halayko², Johan Zaagsma', Herman Meurs ${ }^{1}$
}

\begin{abstract}
Background: Fibroproliferative airway remodelling, including increased airway smooth muscle (ASM) mass and contractility, contributes to airway hyperresponsiveness in asthma. In vitro studies have shown that maturation of ASM cells to a (hyper)contractile phenotype is dependent on laminin, which can be inhibited by the laminincompeting peptide Tyr-lle-Gly-Ser-Arg (YIGSR). The role of laminins in ASM remodelling in chronic asthma in vivo, however, has not yet been established.

Methods: Using an established guinea pig model of allergic asthma, we investigated the effects of topical treatment of the airways with YIGSR on features of airway remodelling induced by repeated allergen challenge, including ASM hyperplasia and hypercontractility, inflammation and fibrosis. Human ASM cells were used to investigate the direct effects of YIGSR on ASM proliferation in vitro.

Results: Topical administration of YIGSR attenuated allergen-induced ASM hyperplasia and pulmonary expression of the proliferative marker proliferating cell nuclear antigen (PCNA). Treatment with YIGSR also increased both the expression of sm-MHC and ASM contractility in saline- and allergen-challenged animals; this suggests that treatment with the laminin-competing peptide YIGSR mimics rather than inhibits laminin function in vivo. In addition, treatment with YIGSR increased allergen-induced fibrosis and submucosal eosinophilia. Immobilized YIGSR concentration-dependently reduced PDGF-induced proliferation of cultured ASM to a similar extent as laminincoated culture plates. Notably, the effects of both immobilized YIGSR and laminin were antagonized by soluble YIGSR.
\end{abstract}

Conclusion: These results indicate that the laminin-competing peptide YIGSR promotes a contractile, hypoproliferative ASM phenotype in vivo, an effect that appears to be linked to the microenvironment in which the cells are exposed to the peptide.

\section{Background}

Airway inflammation, airway obstructive reactions and development of transient airway hyperresponsiveness are primary features of acute asthma [1,2]. In addition, structural changes in the airway wall are thought to contribute to a decline of lung function and development of persistent airway hyperresponsiveness in chronic asthma $[1,3]$. These

\footnotetext{
* Correspondence: b.g.j.dekkers@rug.nl

'Department of Molecular Pharmacology, University of Groningen, Groningen, Netherlands

Full list of author information is available at the end of the article
}

structural changes include goblet cell metaplasia and mucous gland hyperplasia, increased vascularity, altered deposition of the extracellular matrix (ECM) proteins and accumulation of contractile airway smooth muscle (ASM) cells $[1,4-7]$. ASM cells can contribute to airway remodelling as they retain the ability for reversible phenotypic switching, enabling them to exhibit variable contractile, proliferative, migratory and synthetic states [8,9]. In vitro, modulation to a proliferative phenotype results from exposure of ASM cells to mitogenic stimuli, leading to increased proliferative activity and decreased contractile function [10-12].

\section{C) Bïomed Central}


Removal of growth factors, for example by serum deprivation in the presence of insulin, results in maturation of the cells to a contractile phenotype, characterized by increased expression of contractile protein markers, increased contractile function and increased expression of laminin $\alpha 2, \beta 1$ and $\gamma 1$ chains [8,13-15].

Laminins are basement membrane ECM components composed of heterotrimers of $\alpha, \beta$ and $\gamma$ chains. Five laminin $\alpha$-, three $\beta$ - and three $\gamma$-chains have been identified in mammals, which form at least fifteen different laminin isoforms [16]. Various laminin chains are expressed in the lung and expression appears to be tissue- and developmental stage-dependent [17]. In adult asthmatics, expression of laminin $\alpha 2$ and $\beta 2$ chains in the airways is increased $[18,19]$. In addition, asthmatics with compromised epithelial integrity show increased laminin $\gamma 2$ chain expression in the airways [19].

Laminins appear to be essential for lung development and are important determinants of ASM function. Laminin $\alpha 1$ and $\alpha 2$ chains are required for pulmonary branching and differentiation of naïve mesenchymal cells into ASM [16,20,21]. Primary ASM cells cultured on laminin-111 (laminin-1) are retained in a hypoproliferative phenotype, associated with high expression levels of contractile proteins [22]. This is of functional relevance as the induction of a hypocontractile ASM phenotype by PDGF can be prevented by co-incubation with laminin-111 [11]. Increased expression of endogenous laminin-211 (laminin-2) is essential for ASM cell maturation [14], and studies from our laboratory show that laminin-211 is essential for the induction of a hypercontractile, hypoproliferative ASM phenotype by prolonged insulin exposure [15].

Recently, in an animal model of chronic allergic asthma we showed that ASM remodelling can be inhibited by the integrin-blocking peptide Arg-Gly-Asp-Ser (RGDS) [23], which contains the RGD-binding motif present in ECM proteins like fibronectin, collagens and laminins [24,25]. The specific role of laminins in ASM remodelling in vivo, however, remains to be determined. Therefore, using a guinea pig model of chronic asthma, we explored the role of laminins in ASM remodelling in vivo, by treating the animals with the specific soluble laminin-competing peptide Tyr-Ile-Gly-Ser-Arg (YIGSR), a binding motif present in the $\beta 1$ chain of laminins [26].

\section{Methods}

Animals

All protocols described in this study were approved by the University of Groningen Committee for Animal Experimentation. Outbred, male, specified pathogen-free Dunkin Hartley guinea pigs (Harlan, Heathfield, UK) weighing 150-250 g were sensitized to ovalbumin (Sigma Chemical Co., St. Louis, MO, USA), using Al
$(\mathrm{OH})_{3}$ as adjuvant, as described previously [27]. In short, $0.5 \mathrm{ml}$ of an allergen solution containing $100 \mu \mathrm{g} / \mathrm{ml}$ ovalbumin and $100 \mathrm{mg} / \mathrm{ml} \mathrm{Al}(\mathrm{OH})_{3}$ in saline was injected intraperitoneally, while another $0.5 \mathrm{ml}$ was divided over seven intracutaneous injection sites in the proximity of lymph nodes in the paws, lumbar regions and the neck. The animals were group-housed in cages in climate controlled animal quarters and given water and food ad libitum, while a 12-hour on/12-hour off light cycle was maintained.

\section{Provocation Procedures}

Four weeks after sensitization, allergen-provocations were performed by inhalation of aerosolized solutions of saline (control) or ovalbumin as described previously [27]. Aerosols were produced by a DeVilbiss nebulizer (type 646, DeVilbiss, Somerset, PA, USA). Provocations were carried out in a specially designed Perspex cage (internal volume $9 \mathrm{~L}$ ), in which the guinea pigs could move freely. Before the start of the experimental protocol, the animals were habituated to the provocation procedures. After an adaptation period of $30 \mathrm{~min}$, three consecutive provocations with saline were performed, each provocation lasting $3 \mathrm{~min}$, separated by $7 \mathrm{~min}$ intervals. Ovalbumin challenges were performed by inhalation of increasing concentrations of ovalbumin $(0.5,1.0$, or $3.0 \mathrm{mg} / \mathrm{ml})$ in saline. Allergen inhalations were discontinued when the first signs of respiratory distress were observed. No anti-histaminic was needed to prevent the development of anaphylactic shock.

\section{Study design}

Guinea pigs were challenged with either saline or ovalbumin once weekly for 12 consecutive weeks, as described previously $[23,28,29]$. Animals were treated with saline or YIGSR (Calbiochem, Nottingham, UK) by intranasal instillation $(2.5 \mathrm{mM}, 200 \mu \mathrm{l}), 0.5 \mathrm{hr}$ prior to and $5.5 \mathrm{hr}$ after each challenge with saline or ovalbumin, as described previously for RGDS [23]. Treatment groups were as follows: saline-treated, saline-challenged controls $(n=6)$; YIGSR-treated, saline-challenged animals ( $\mathrm{n}=5)$; saline-treated, ovalbumin-challenged animals $(n=7)$ and YIGSR-treated, ovalbumin-challenged animals $(n=7)$. Data for the saline-treated animals (controls) have been published previously as part of a simultaneous parallel study [23]. During the 12-week challenge protocol, guinea pig weight was monitored weekly and no differences in weight gain between different treatment groups were found

\section{Tissue acquisition}

Guinea pigs were sacrificed by experimental concussion, followed by rapid exsanguination $24 \mathrm{~h}$ after the last challenge. The lungs were immediately resected and 
kept on ice for further processing. The trachea was removed and transferred to a Krebs-Henseleit $(\mathrm{KH})$ buffer of the following composition (mM): $117.5 \mathrm{NaCl}, 5.60$ $\mathrm{KCl}, 1.18 \mathrm{MgSO}_{4}, 2.50 \mathrm{CaCl}_{2}, 1.28 \mathrm{NaH}_{2} \mathrm{PO}_{4}, 25.00$ $\mathrm{NaHCO}_{3}$, and 5.50 glucose, pregassed with $5 \% \mathrm{CO}_{2}$ and $95 \% \mathrm{O}_{2}, \mathrm{pH} 7.4$ at $37^{\circ} \mathrm{C}$. Lungs were divided into three parts and weighed. One part was snap frozen in liquid nitrogen for the measurement of hydroxyproline content. One part was frozen at $-80^{\circ} \mathrm{C}$ in isopentane and stored at $-80^{\circ} \mathrm{C}$ for histological purposes. The remaining part was snap frozen in liquid nitrogen and stored at $-80^{\circ} \mathrm{C}$ to be used for Western analysis.

\section{Isometric tension measurements}

Isometric contraction experiments were performed as described previously $[23,28,29]$. Briefly, the trachea was prepared free of connective tissue. Single open-ring, epithelium-denuded preparations were mounted for isometric recording in organ baths, containing $\mathrm{KH}$ buffer at $37^{\circ} \mathrm{C}$, continuously gassed with $5 \% \mathrm{CO}_{2}$ and $95 \% \mathrm{O}_{2}, \mathrm{pH}$ 7.4. During a 90 -min equilibration period, resting tension was gradually adjusted to $0.5 \mathrm{~g}$. Subsequently, muscle strips were precontracted with $20 \mathrm{mM}$ and $40 \mathrm{mM} \mathrm{KCl}$. Following washouts, maximal relaxation was established by the addition of $0.1 \mu \mathrm{M}(-)$-isoproterenol (Sigma). After washout and another $30 \mathrm{~min}$ equilibration period, cumulative concentration-response curves were constructed using stepwise increasing concentrations of $\mathrm{KCl}$ (5.6-50 mM) or methacholine (1 nM - $0.1 \mathrm{mM})$. When maximal tension was reached, the strips were washed several times and maximal relaxation was established using $10 \mu \mathrm{M}$ (-)-isoproterenol.

\section{Histochemistry}

Immunohistochemistry was performed as described previously $[23,28,29]$. Transverse cross-sections $(8 \mu \mathrm{m})$ of the main bronchi from both right and left lung lobes were used for morphometric analyses. To identify smooth muscle, the sections were stained for smooth-muscle-specific myosin heavy chain (sm-MHC). Sections were dried, fixed with acetone and washed in phosphate-buffered saline (PBS). Subsequently, sections were incubated for $1 \mathrm{~h}$ in PBS supplemented with $1 \%$ bovine serum albumin (BSA, Sigma) and anti-sm-MHC (diluted 1:100, Neomarkers, Fremont, CA, USA) at room temperature. Sections were then washed with PBS, after which endogenous peroxidase activity was blocked by treatment with PBS containing $0.075 \% \mathrm{H}_{2} \mathrm{O}_{2}$ for $30 \mathrm{~min}$. Sections were washed with PBS, after which the horseradish peroxidase (HRP)-linked secondary antibody (rabbit anti-mouse IgG, Sigma, diluted 1:200) was applied for $30 \mathrm{~min}$ at room temperature. After another three washes, sections were incubated with diaminobenzidine $(1 \mathrm{mg} / \mathrm{ml})$ for $5 \mathrm{~min}$ in the dark, after which sections were washed and stained with haematoxylin. After rinsing with water the sections were embedded in
Kaisers glycerol gelatin. Airways within sections were digitally photographed and subclassified as cartilaginous or non-cartilaginous. All immunohistochemical measurements were carried out digitally, using quantification software (ImageJ). For this purpose, digital photographs of lung sections were analyzed at a magnification of 40-100x. For both types of airways, sm-MHC positive areas were measured by a single observer in a blinded fashion. In addition, haematoxylin-stained nuclei within the ASM bundle were counted. Of each animal, 4 lung sections were prepared per immunohistochemical staining, in which a total of 4 to 5 airways of each classification were analyzed. Eosinophils were identified in haematoxylinand-eosin-stained lung sections.

\section{Western analysis}

Lung homogenates were prepared as described previously $[23,28,29]$. Equal amounts of protein were subjected to electrophoresis and transferred onto nitrocellulose membranes, followed by immunoblotting for $s m-\mathrm{MHC}$ and PCNA (Neomarkers), using standard techniques. Antibodies were visualized on film using enhanced chemiluminescence reagents (Pierce, Rockford, IL, USA) and analyzed by densitometry (Totallab ${ }^{\mathrm{Tm}}$, Nonlinear dynamics, Newcastle, UK). All bands were normalized to $\beta$-actin expression.

\section{Hydroxyproline assay}

Lungs were analyzed for hydroxyproline, an estimate of collagen content, as described previously [23]. In short, total lung homogenates were prepared by pulverizing tissue under liquid nitrogen and sonification in PBS. Homogenates were incubated with 1,25 ml 5\% trichloroacetic acid on ice for $20 \mathrm{~min}$, after which the samples were centrifuged. The pellet was resuspended in $12 \mathrm{~N}$ hydrochloric acid $(10 \mathrm{ml})$ and heated overnight at $110^{\circ} \mathrm{C}$. The samples were dissolved in $2 \mathrm{ml}$ water by incubating for $72 \mathrm{~h}$ at room temperature. To determine hydroxyproline concentrations, samples were incubated with $100 \mu \mathrm{l}$ chloramine $\mathrm{T}$ (1.4\% chloramine $\mathrm{T}$ in $0.5 \mathrm{M}$ sodium acetate/10\% isopropanol) for $30 \mathrm{~min}$ at room temperature. Next, $100 \mu$ l Ehrlich's solution (1.0 M 4-dimethylaminobenzaldehyde in $70 \%$ isopropanol/30\% perchloric acid) was added and samples were incubated at $65^{\circ} \mathrm{C}$ for 30 min. Samples were cooled to room temperature and hydroxyproline concentrations were quantified by colorimetric measurement (550 nm, Biorad 680 plate reader).

\section{Cell culture}

Three human bronchial smooth muscle cell lines, immortalized by stable expression of human telomerase reverse transcriptase (hTERT), were used for all experiments. The primary cells used to generate each cell line were prepared as we have described [30-32]. All 
procedures were approved by the Human Research Ethics Board of the University of Manitoba. For all experiments, passages 26-34 myocytes grown on uncoated plastic dishes in Dulbecco's Modified Eagle's Medium (DMEM, Gibco BRL Life Technologies, Paisley, U.K.) supplemented with $50 \mathrm{U} / \mathrm{ml}$ streptomycin, $50 \mu \mathrm{g} /$ $\mathrm{ml}$ penicillin, (Gibco) and 10\% vol/vol Foetal Bovine Serum (FBS, Gibco) were used.

\section{Coating of culture plates with laminin and integrin- blocking peptides}

Dilutions of mouse Engelberth-Holm-Swarm (EHS) laminin-111 (10 $\mu \mathrm{g} / \mathrm{ml}$, Invitrogen, Grand Island, NY, USA), YIGSR (1-100 $\mu \mathrm{M}$ ), Arg-Gly-Asp-Ser (RGDS, $100 \mu \mathrm{M}$, Calbiochem) and Gly-Arg-Ala-Asp-Ser-Pro (GRADSP, $100 \mu \mathrm{M}$, Calbiochem) were prepared in PBS and absorbed to 24-well culture plates overnight. Unoccupied proteinbinding sites were blocked by a 30-min incubation with $0.1 \%$ BSA in PBS. Subsequently, plates were washed twice with plain DMEM and dried before further use.

\section{$\left[{ }^{3} \mathrm{H}\right]$-Thymidine incorporation}

Cells in DMEM supplemented with streptomycin, penicillin and 10\% FBS were plated on uncoated or coated 24well culture plates at a density of 20,000 cells per well and allowed to attach overnight. Subsequently, cells were maintained in serum-free DMEM supplemented with antibiotics and 1\% ITS (Insulin, Transferrin and Selenium, Gibco) for 3 days. Cells were then incubated with or without PDGF-AB (10 ng/ml, human, Bachem, Weil am Rhein, Germany) for $28 \mathrm{~h}$, the last $24 \mathrm{~h}$ in the presence of [methyl- ${ }^{3} \mathrm{H}$ ]-thymidine $(0.25 \mu \mathrm{Ci} / \mathrm{ml})$ in DMEM supplemented with antibiotics. After incubation, the cells were washed twice with $0.5 \mathrm{ml}$ PBS at room temperature. Subsequently, the cells were treated with $0.5 \mathrm{ml}$ ice-cold $5 \%$ trichloroacetic acid on ice for $30 \mathrm{~min}$, and the acidinsoluble fraction was dissolved in $1 \mathrm{ml} \mathrm{NaOH}(1 \mathrm{M})$. Incorporated $\left[{ }^{3} \mathrm{H}\right]$-thymidine was quantified by liquidscintillation counting using a Beckman LS1701 $\beta$-counter.

\section{Statistics}

All data represent means \pm SEM from $n$ separate experiments. Statistical significance of differences was evaluated using one-way ANOVA, followed by a Newman-Keuls multiple comparisons test. Differences were considered to be statistically significant when $\mathrm{P}<0.05$.

\section{Results}

The laminin $\beta 1$-competing peptide YIGSR inhibits allergen-induced ASM accumulation in a guinea pig model of chronic allergic asthma

In our guinea pig model repeated ovalbumin-challenge increased $s m$-MHC-positive area - corresponding to
ASM - predominantly in the cartilaginous airways by 1.9 \pm 0.1 -fold ( $\mathrm{P}<0.001)$ compared to saline-treated, salinechallenged controls (Figure 1A). Topical treatment of the airways with intranasally instilled YIGSR $0.5 \mathrm{~h}$ prior to and $5.5 \mathrm{~h}$ after each ovalbumin-challenge nearly abrogated ovalbumin-induced increase in ASM mass (by 96 $\pm 3 \%, \mathrm{P}<0.001)$. No significant effect of YIGSR treatment was observed in saline-challenged animals.

To determine whether the changes in ASM content were associated with changes in cell number and/or cell size, the number of nuclei within the ASM layer were counted and expressed relative to total ASM area. Repeated ovalbumin challenge did not change the number of nuclei per $\mathrm{mm}^{2}$ of smooth muscle area (Figure $1 \mathrm{~B})$, indicating that the cell size is unchanged and ovalbumin-induced increases in ASM mass were caused by increased cell number (hyperplasia). YIGSR treatment did not change ASM cell size in saline-challenged animals; however, a small, but significant $(P<0.05)$ decrease in the number of nuclei $/ \mathrm{mm}^{2}$ was observed in ovalbumin-challenged animals (Figure 1B), suggesting that this treatment may lead to some increase in cell size (hypertrophy).

To assess whether the changes in ASM area were associated with changes in proliferative responses, immunoblotting was used to determine expression of the proliferation marker, PCNA, in whole lung homogenates. After repeated ovalbumin-challenge, a considerable increase $(4.2 \pm 0.2$-fold, $\mathrm{P}<0.001)$ in PCNA was observed compared to saline-treated, saline-challenged controls (Figure 1C). Treatment with YIGSR fully normalized the ovalbumin-induced increase in PCNA, when compared to saline-challenged controls $(P<0.001)$. In the salinechallenged animals, no significant effect of YIGSR treatment on PCNA expression was observed. Unfortunately, specific characterization of the proliferating cells in guinea pig lung sections by immunohistochemistry was not possible with the antibody used. Collectively, these in vivo data indicate that YIGSR treatment inhibits allergen-induced ASM hyperplasia in association with suppressing proliferative responses of lung cells.

\section{YIGSR treatment increases contractile protein accumulation and ASM contractility}

Previously, we showed that repeated ovalbuminexposure increased maximal methacholine- and $\mathrm{KCl}$ induced isometric contraction of epithelium-denuded, tracheal smooth muscle preparations ex vivo [23,28,29]. Interestingly, treatment with the YIGSR peptide augmented the ovalbumin-induced increase in maximal methacholine- and $\mathrm{KCl}$-induced contractions by $1.33 \pm 0.08$-fold $(\mathrm{P}<0.001)$ and $1.28 \pm 0.11$-fold $(\mathrm{P}<0.05)$, respectively, compared to saline-treated, ovalbumin-challenged controls 


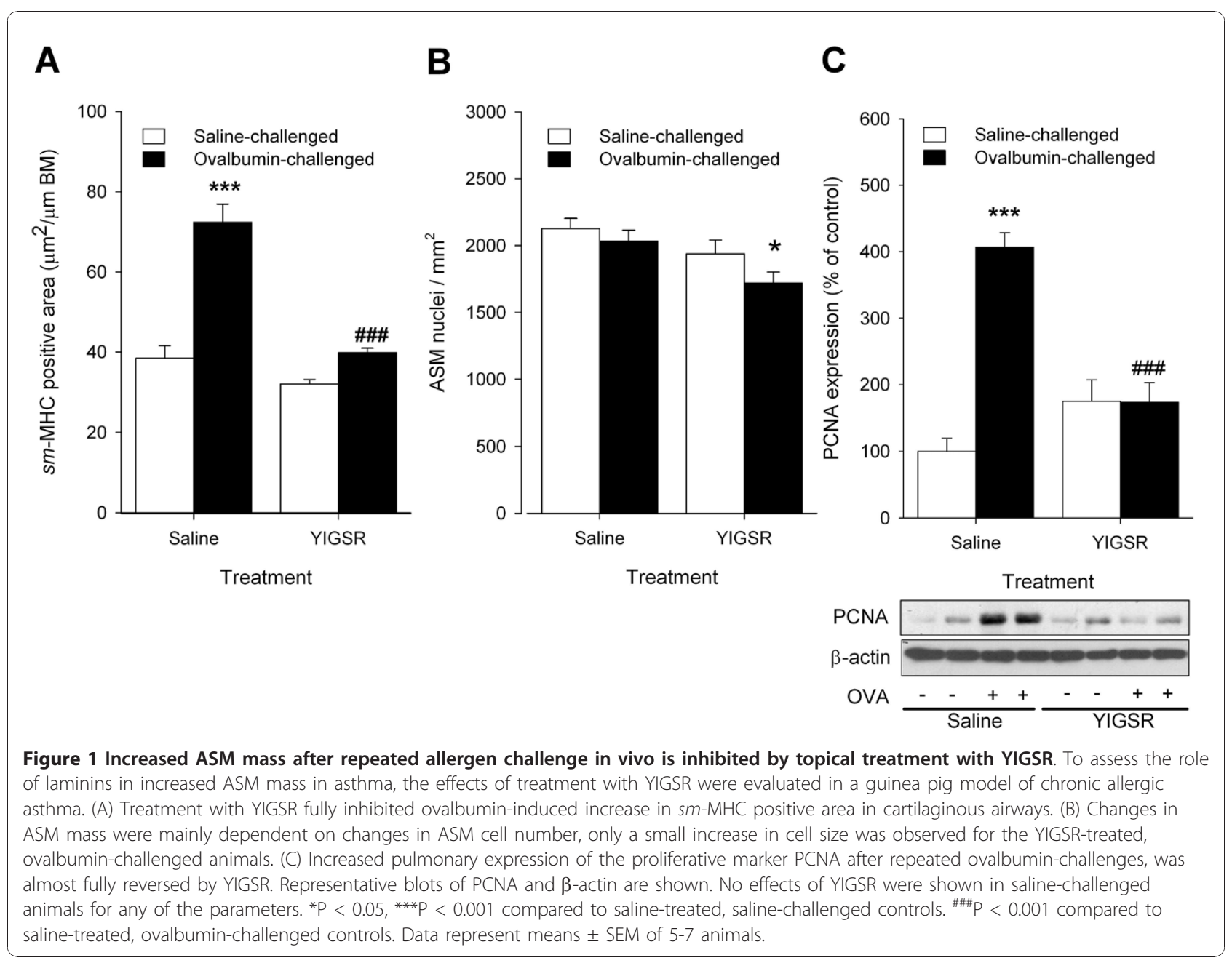

(Figure 2A and Table 1). Similarly, in saline-challenged animals YIGSR treatment increased methacholine- and $\mathrm{KCl}$-induced contraction $(1.29 \pm 0.03$-fold and $1.39 \pm$ 0.04-fold $(\mathrm{P}<0.05)$, respectively). The sensitivity to either contractile stimulus was unaffected by treatment (Table 1). Previously, we found that increased ASM contractility induced by allergen challenge is associated with increased pulmonary sm-MHC expression [23,28,29]. In saline-treated animals, repeated ovalbumin-challenge increased smMHC by $2.5 \pm 0.1$-fold compared to saline-challenged controls $(\mathrm{P}<0.001$, Figure $2 \mathrm{~B})$. In line with the increased methacholine- and $\mathrm{KCl}$-induced contractions, treatment with YIGSR increased pulmonary $s m-\mathrm{MHC}$ expression in saline-challenged animals $(2.40 \pm 0.28$-fold, $\mathrm{P}<0.001)$, whereas in ovalbumin-challenged animals the increase in $s m$-MHC was increased further $(1.37 \pm 0.08$-fold compared to ovalbumin-challenged controls, $\mathrm{P}<0.01)$. Collectively, these data indicate that in vivo treatment with the laminin-competing peptide YIGSR increases ASM contractility and contractile protein expression both in salineand allergen-challenged animals.
Effects of YIGSR treatment on allergen-induced airway inflammation

Infiltration of eosinophils into the airways is a characteristic feature of allergic asthma and is generally considered to contribute to airway remodelling [2]. As observed previously [23,28], repeated ovalbumin challenge increased the number of eosinophils in the submucosal and adventitial compartments of the airways $(\mathrm{P}<0.001$ both, Figure $3 \mathrm{~A}$ and $3 \mathrm{~B})$. No significant effect of YIGSR on eosinophil number in the adventitial compartment was observed in ovalbumin- and salinechallenged animals (Figure 3B). However, YIGSR significantly increased eosinophil number in the submucosal airway compartment after repeated allergen challenge $(\mathrm{P}<0.05$, Figure 3A).

\section{Effects of YIGSR treatment on allergen-induced fibrosis} Aberrant deposition of ECM proteins, including collagens, in the airway wall is another characteristic feature of chronic asthma [33,34]. As observed previously [23], we demonstrated that lung hydroxyproline content, 

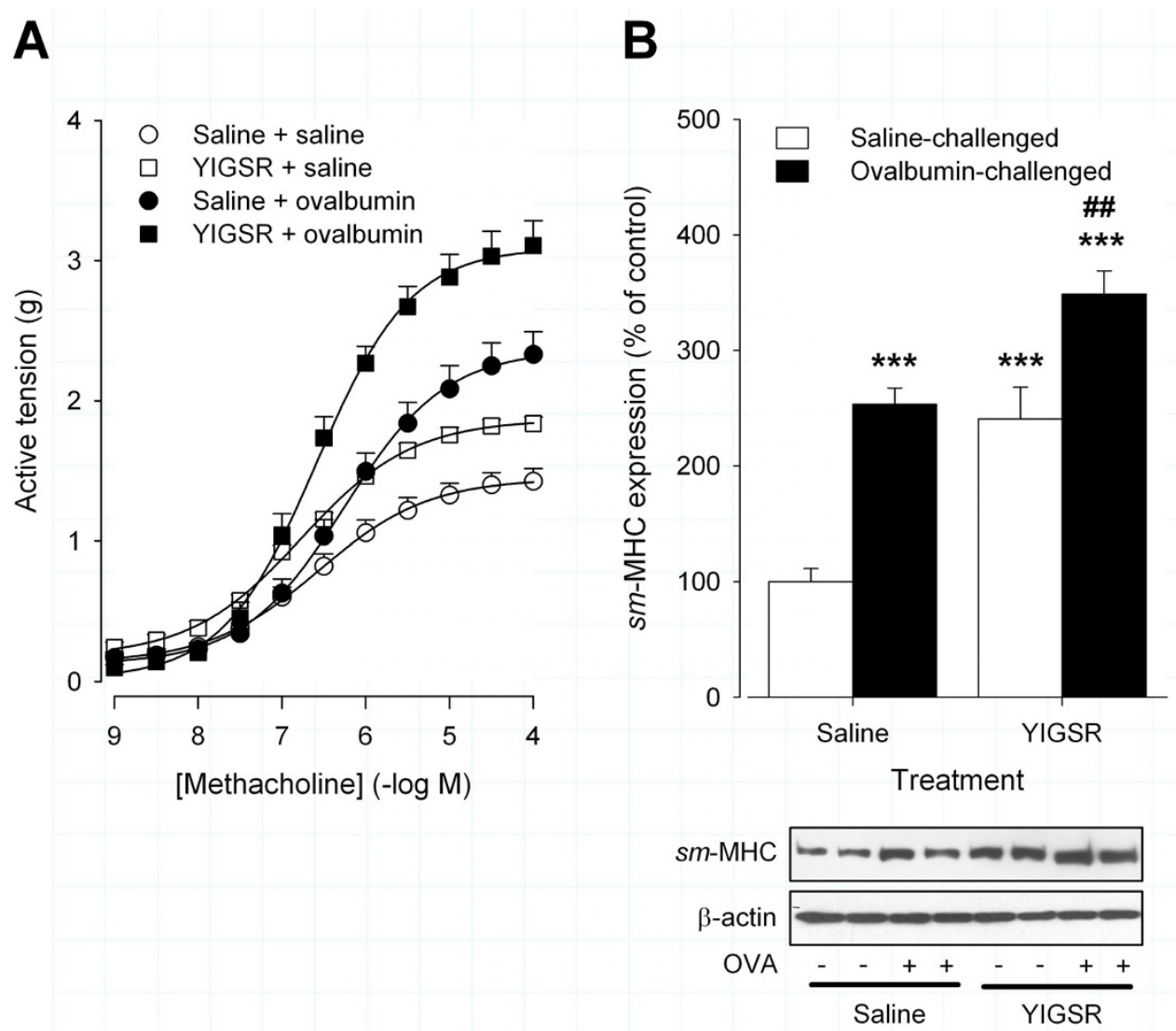

Figure 2 Topical treatment of the airways with YIGSR increases ASM contractility and contractile protein accumulation. (A) Treatment with YIGSR enhanced the maximal methacholine-induced isometric contraction of epithelium-denuded tracheal smooth muscle preparations both in saline- and in ovalbumin-challenged animals. (B) Treatment with YIGSR increased pulmonary expression of sm-MHC, both in saline- and in ovalbumin-challenged animals. Representative blots of $s m-\mathrm{MHC}$ and $\beta$-actin are shown. ${ }^{* * *} \mathrm{P}<0.001$ compared to saline-treated, salinechallenged controls. ${ }^{\# \#} \mathrm{P}<0.01$ compared to saline-treated, ovalbumin-challenged controls. Data represent means \pm SEM of 5-7 animals.

as an estimate of collagen, is increased after repeated ovalbumin challenge $(\mathrm{P}<0.001$, Figure 4$)$. Treatment with YIGSR of the ovalbumin-challenged animals further augmented the hydroxyproline content $(\mathrm{P}<$ 0.01 ), but did not change the hydroxyproline content in saline-challenged animals. Collectively, our findings indicate that YIGSR treatment increases allergen-induced submucosal airway eosinophilia as well as collagen deposition in the lung.

Immobilized YIGSR inhibits ASM cell proliferation in vitro In comparison to the in vivo data from our current study, it is paradoxical that previous in vitro studies have indicated that soluble YIGSR inhibits ASM cell

Table 1 Contractile responses of epithelium-denuded, tracheal smooth muscle preparations after repeated saline or ovalbumin challenge of saline- or YIGSR-treated guinea pigs

\begin{tabular}{|c|c|c|c|c|c|c|}
\hline \multirow[t]{2}{*}{ Treatment } & \multirow[t]{2}{*}{ Challenge } & \multicolumn{2}{|l|}{ Methacholine } & \multicolumn{2}{|l|}{$\mathrm{KCl}$} & \multirow[t]{2}{*}{$n$} \\
\hline & & $E_{\max }(g)$ & $p E C_{50}(-\log M)$ & $E_{\max }(g)$ & $\mathrm{EC}_{50}(\mathrm{mM})$ & \\
\hline Saline & Saline & $1.42 \pm 0.09$ & $6.55 \pm 0.18$ & $1.02 \pm 0.06$ & $23.7 \pm 0.9$ & 6 \\
\hline YIGSR & Saline & $1.84 \pm 0.04$ & $6.82 \pm 0.13$ & $1.41 \pm 0.04^{*}$ & $20.4 \pm 2.2$ & 5 \\
\hline Saline & Ovalbumin & $2.33 \pm 0.22^{* * *}$ & $6.28 \pm 0.11$ & $1.73 \pm 0.13^{* *}$ & $23.7 \pm 1.2$ & 7 \\
\hline YIGSR & Ovalbumin & 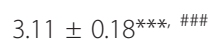 & $6.61 \pm 0.08$ & $2.12 \pm 0.19^{* * *, \#}$ & $24.5 \pm 1.1$ & 7 \\
\hline
\end{tabular}

Data represent means $\pm \mathrm{SEM}$. Abbreviations: $\mathrm{E}_{\max }$ : maximal contractile effect; $\mathrm{EC}_{50}$ : concentration of the stimulus eliciting half-maximal response; $\mathrm{pEC} \mathrm{C}_{50}$ : negative logarithm of the $\mathrm{EC}_{50}$ value. ${ }^{* \mathrm{P}}<0.05$, ${ }^{* * \mathrm{P}}<0.01$, ${ }^{* *} \mathrm{P}<0.001$ compared to saline-treated, saline-challenged animals. $\mathrm{P}<0.05$, ${ }^{\# \# \#} \mathrm{P}<0.001$ compared to salinetreated, ovalbumin-challenged animals. 


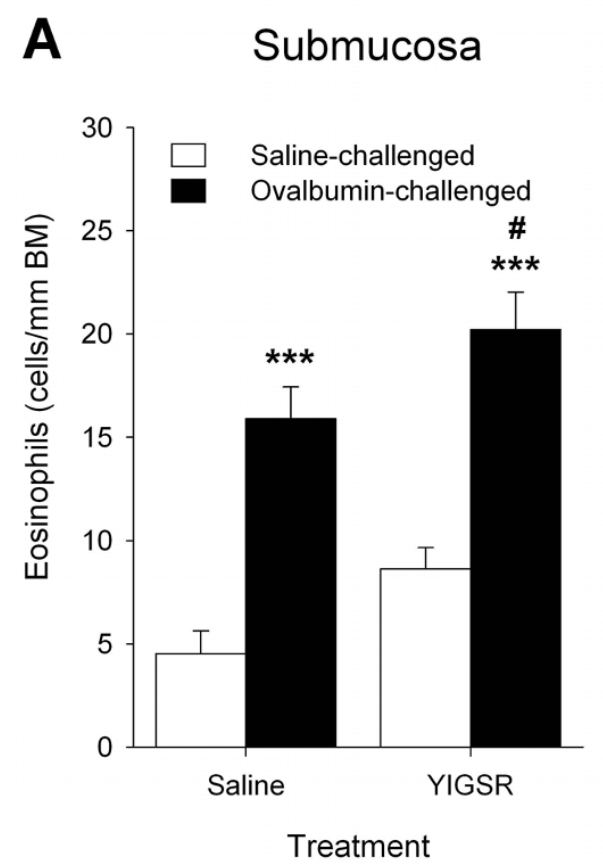

\section{B Adventitia}

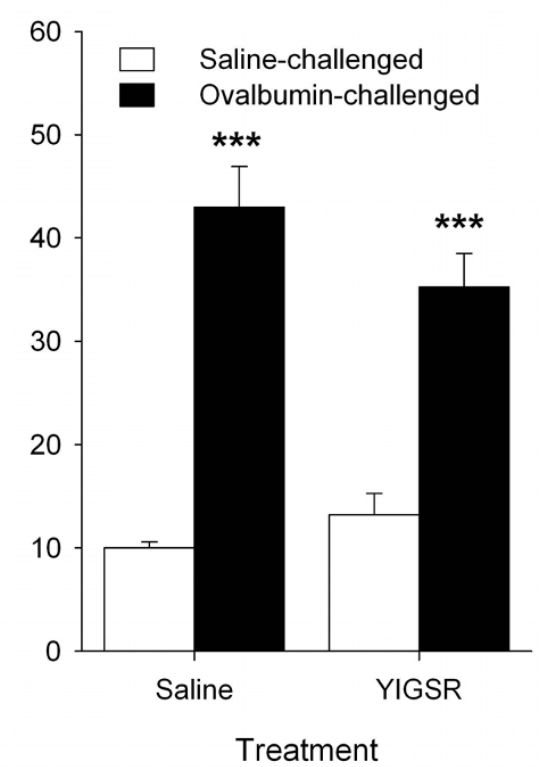

Figure 3 YIGSR treatment increases allergen-induced eosinophilic inflammation in the submucosal airway compartment. (A) Ovalbumin-induced eosinophil numbers in the submucosal compartment are increased by YIGSR treatment. (B) YIGSR treatment does not affect eosinophilic cell number in the adventitial compartment. No effects of YIGSR were found in saline-challenged animals for any of the conditions. ${ }^{* *} \mathrm{P}<0.001$ compared to saline-treated, saline-challenged controls. ${ }^{*} \mathrm{P}<0.05$ compared to saline-treated, ovalbumin-challenged animals. Data represent means \pm SEM of 5-7 animals.

maturation and development of a hypercontractile, hypoproliferative phenotype [14,15]. However, previous in vitro experiments have revealed that YIGSR may both mimic and inhibit laminin function, depending on the physicochemical conditions $[26,35,36]$. Thus, when immobilized, YIGSR promotes cell adhesion of various cells, similar to laminin $[26,35,36]$. However, soluble YIGSR blocks cell adhesion to laminin-111 [35]. To further investigate whether this may also apply to ASM cells, the effects of immobilized and soluble YIGSR on basal and growth factor-induced ASM cell proliferation were compared in vitro. First, human ASM cells were cultured on 24 well plates coated with increasing concentrations of YIGSR (1-100 $\mu \mathrm{M})$ and stimulated with PDGF (10 ng/ml). Culturing the cells on immobilized YIGSR concentration-dependently inhibited PDGFinduced DNA synthesis (Figure 5A) and cell number (not shown), but no effect was observed on basal DNA synthesis. By contrast, culturing cells on immobilized RGDS $(100 \mu \mathrm{M})$ or its negative control peptide GlyArg-Ala-Asp-Ser-Pro (GRADSP, $100 \mu \mathrm{M}$ ) did not affect basal or PDGF-induced proliferation (Figure 5B).

To assess the effects of soluble YIGSR on proliferative responses of human ASM, cells were cultured on immobilized laminin-111 $(10 \mu \mathrm{g} / \mathrm{ml})$ or YIGSR $(100 \mu \mathrm{M})$. Subsequently, cells were stimulated with vehicle or PDGF in the absence or presence of soluble YIGSR. As observed previously $[11,15]$, we found that culturing on laminin111 inhibited PDGF-induced DNA-synthesis (by $56 \pm$ $11 \%, \mathrm{P}<0.05$, Figure $5 \mathrm{C}$ ) and cell number (not shown). This inhibitory effect was fully reversed by soluble YIGSR. Surprisingly, the inhibitory effect of coated YIGSR on PDGF-induced proliferation was also fully normalized by soluble YIGSR. Of note, we have reported previously that this peptide did not affect basal or PDGF-induced proliferative responses in the absence of laminin-111 [15]. Collectively, these results indicate that the effects of the laminin-competing peptide YIGSR on ASM proliferative responses may depend on the peptide microenvironment (i.e. soluble versus immobilized).

\section{Discussion}

In the current study, we demonstrate that treatment with the laminin $\beta 1$ chain-competing peptide YIGSR promotes the formation of a hypercontractile, hypoproliferative ASM phenotype in an animal model of chronic asthma. Topical application of YIGSR to the airways inhibited ASM hyperplasia induced by repeated allergen challenge. However, ASM contractility and contractile protein expression were increased under basal and allergenchallenged conditions. These results appear to be in contrast to previous in vitro studies, demonstrating that 


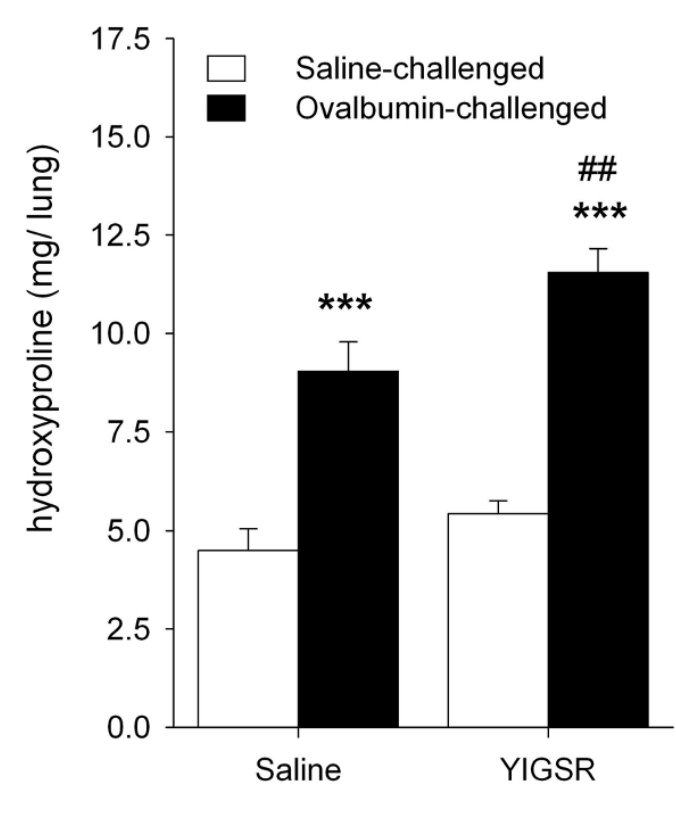

Treatment

Figure 4 YIGSR treatment increases allergen-induced fibrosis in the guinea pig lung. Hydroxyproline content in guinea pig lung after repeated saline- or ovalbumin-challenges in saline- and YIGSRtreated animals. ${ }^{* *} \mathrm{P}<0.001$ compared to saline-treated, salinechallenged controls. ${ }^{\# \#} \mathrm{P}<0.01$ compared to saline-treated, ovalbumin-challenged animals. Data represent means \pm SEM of 5-7 animals.

soluble YIGSR inhibits maturation of human ASM cells to a hypercontractile, hypoproliferative ASM phenotype $[14,15]$.

Accumulation of ASM in the airway wall is a characteristic feature of asthma, which may be due to an increase in cell number (hyperplasia) $[37,38]$ as well as an increase in cell size (hypertrophy) [37,39]. This ASM accumulation contributes importantly to increased airway resistance and airway hyperresponsiveness $[40,41]$. Switching of the ASM phenotype from a contractile to a proliferative state is thought to contribute to the increased ASM mass in asthma [9]. In support, various mitogenic stimuli, including growth factors and ECM proteins, induce a proliferative ASM phenotype in vitro [10-12], an effect that can be inhibited by culturing the cells on immobilized laminin-111 $[11,22,23]$ or endogenously produced laminin-211 [15]. These inhibitory effects can be reversed using soluble YIGSR [15], a binding motif present in the laminin $\beta 1$ chain [26]. Similarly, in our study culturing human ASM cells on laminin-111 reduced PDGF-induced proliferation, an effect fully normalized by soluble YIGSR. In contrast to this effect of soluble YIGSR, we also show that immobilized YIGSR concentration-dependently inhibited growth factor-induced myocyte proliferation to the same extent as laminin-111. Interestingly, previous work has also shown a disparate effect of immobilized and soluble YIGSR, with the former promoting attachment of various cells $[26,35,36]$ whereas the latter blocked attachment to laminin-111 [35] or matrigel [36]. The effects of immobilized YIGSR peptide are specific, as culturing on RGDS or GRADSP did not alter proliferation. Of note, addition of soluble YIGSR normalized the effects of immobilized YIGSR, an affect consistent with studies using alveolar cells and a laminin $\alpha$ chain peptide (Ser-Ile-Asn-Asn-Asn-Arg, or SINNNR) [42]. Collectively, these findings suggest that the laminin-competing peptide YIGSR may either promote or inhibit ASM proliferative responses, depending on the microenvironment of the peptide. The mechanisms underlying these differential effects are unknown. However, since the anti-mitogenic effects of the peptide are only observed when the peptide is immobilized, we speculate that this may be associated with bridging of the $67 \mathrm{kDa}$ laminin receptor LAMR1 - which has high affinity to the YIGSR motif [43] - whereas soluble YIGSR may competitively inhibit this type of interaction. Similarly, it has been established that binding of ECM proteins such as fibronectin as a monovalent or multivalent ligand to $\alpha 5 \beta 1$ integrin has diverse effects on focal contacts, tyrosine kinase activation and cytoskeletal dynamics [44]. Our data indicate that future studies of the ligation of soluble and immobilized YIGSR peptides to specific cell surface receptors and resulting intracellular signaling events are needed.

In addition to ASM accumulation, increased expression of contractile proteins and ASM contractility, and ECM deposition are features of airway remodelling in asthma [7]. In the airways of asthmatics increased expression of laminin $\alpha 2$ and $\beta 2$ chains is observed $[18,19]$, and laminin $\gamma 2$ chain expression inversely correlates with epithelial integrity [19]. Laminins have not only been shown to inhibit ASM proliferation, but also to be critical in maintenance and induction of a (hyper) contractile ASM phenotype. Indeed, culturing of ASM cells on a laminin-111 matrix inhibits proliferation $[11,22,23]$, maintains contractile protein expression in the presence of growth factors [22], and prevents induction of a hypocontractile phenotype by PDGF [11]. Induction of a contractile ASM phenotype in serum-free culture supplemented with insulin is associated with increased expression of laminin $\alpha 2, \beta 1$ and $\gamma 1$ chains, all found in the laminin-211 isoform [14,15]. Importantly, the expression of endogenous laminin is required for phenotype maturation, as soluble YIGSR prevents contractile protein accumulation and hypercontractility $[14,15]$. Recently, using our guinea pig model of chronic asthma we showed that treatment with the RGD- 
A

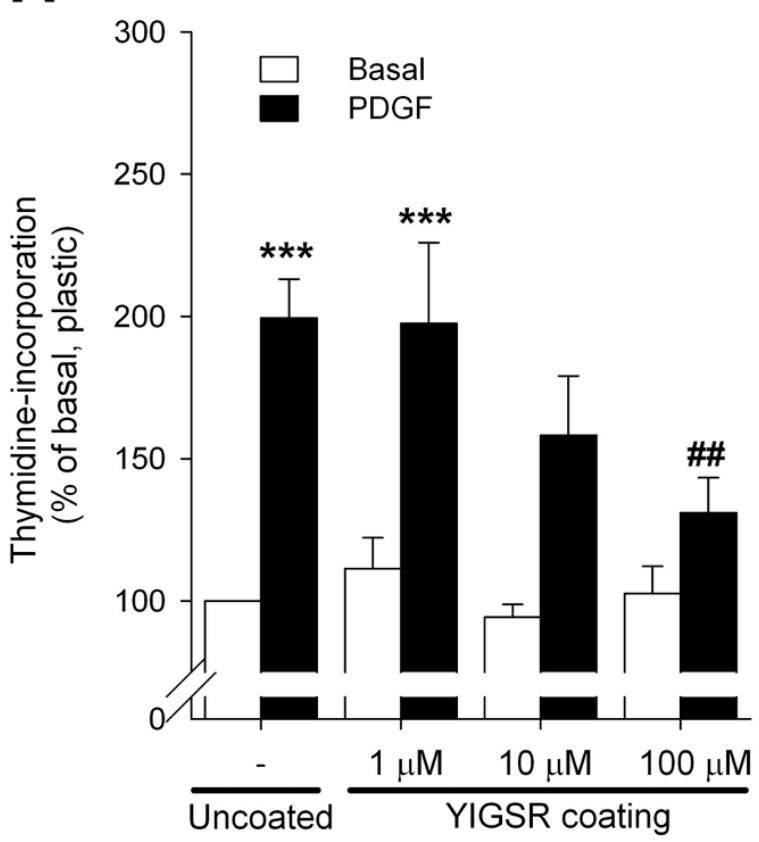

B

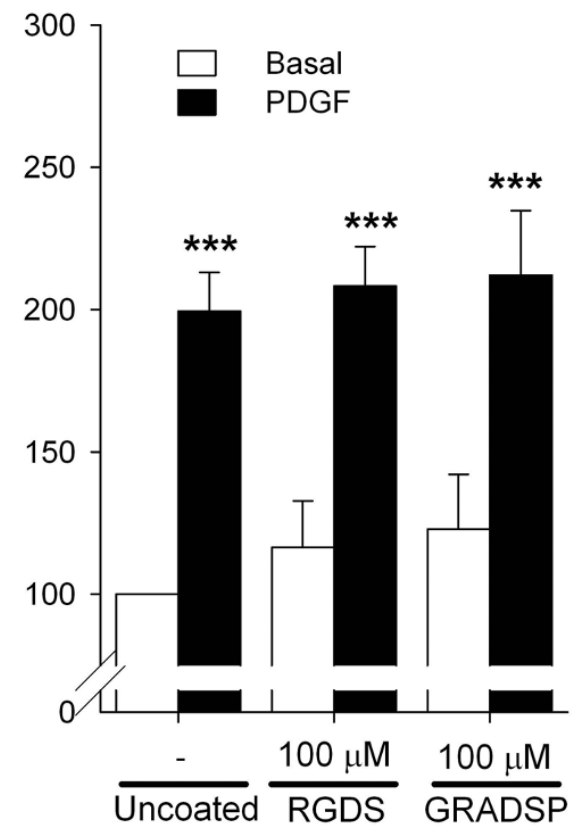

C

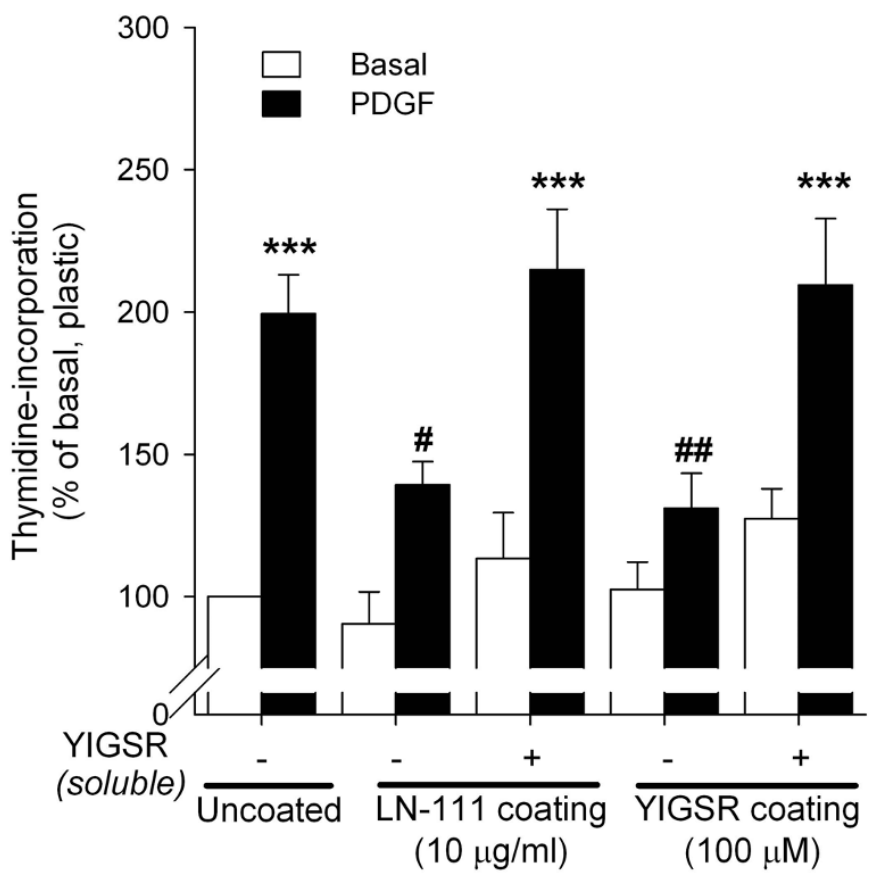

Figure 5 Effects of immobilized and soluble YIGSR on basal and PDGF-induced human ASM cell proliferation. (A) Culturing of human ASM cells on immobilized YIGSR matrices inhibits PDGF-induced thymidine-incorporation in a YIGSR concentration-dependent fashion. Under unstimulated (Basal) conditions, no effects of immobilized YIGSR were observed. (B) Immobilized RGDS or its negative control GRADSP did not affect basal or PDGF-induced thymidine-incorporation. (C) The inhibitory effects of immobilized laminin-111 and YIGSR matrices on PDGFinduced thymidine-incorporation were normalized by soluble YIGSR. ${ }^{* *} \mathrm{P}<0.001$ compared to thymidine-incorporation of unstimulated cells (basal) cultured on uncoated matrices (plastic). ${ }^{\#} \mathrm{P}<0.05$ and ${ }^{\# \#} \mathrm{P}<0.01$ compared to PDGF-induced thymidine-incorporation of cells cultured on uncoated matrices. Data represent means \pm SEM of 4-5 independent experiments of 3 different donors, performed in duplicate. 
containing RGDS peptide largely inhibits ASM hyperplasia and hypercontractility [23]. The RGD sequence exists in several ECM proteins $[24,25]$, thus the specific contribution of laminins cannot be discerned from these prior studies. In the present study we found that in vivo treatment with YIGSR inhibited allergen-induced ASM hyperplasia, but increased both the expression of smMHC and ASM contractility. In addition, a small increase in cell size in the allergen-challenged YIGSR treated animals was observed suggesting that hypertrophy may also have played a role in the observed effects. Collectively, our results indicate that treatment with YIGSR inhibits allergen-induced ASM hyperplasia and increases ASM contractility in vivo, suggesting that YIGSR mimics and/or promotes rather than inhibits laminin function under this condition.

Eosinophils express a number of integrins, of which the $\alpha 6 \beta 1$ mediates adhesion to laminin, but not to collagen type I or type IV [45,46]. Eosinophils isolated from allergic donors show higher adhesion to laminin than those isolated from healthy subjects [46]. Migration of eosinophils through matrigel, a basement membrane extract containing laminin-111, also requires interaction with $\beta 1$-integrins [46]. These findings suggest that laminin-competing peptides could affect allergen-induced airway infiltration of inflammatory cells. To date no reports on YIGSR effects on eosinophil migration are available. In our study we noted that YIGSR increased allergen-induced eosinophil cell numbers in the submucosal compartment, without affecting eosinophil numbers in the adventitial compartment. The increased number of eosinophils in the submucosa suggests that, rather than, infiltration, retention time of the eosinophils in the compartment could be increased. Importantly, increased ECM deposition may be secondary to prolonged airway inflammation [2] and therefore increased allergen-induced airway fibrosis in YIGSRtreated animals could also indirectly result from increased eosinophilia. As increased and altered deposition of ECM proteins, including laminins and collagens, is a feature of remodelling in chronic asthma [33,34] it is important that further investigation focus on understanding the effects of YIGSR and laminins on ECM deposition by fibroblasts and other structural cells.

In summary, our results indicate that the laminincompeting peptide YIGSR promotes a contractile, hypoproliferative ASM phenotype in vivo, an effect that is in striking contrast to current and previously reported evidence showing that soluble YIGSR prevents laminindependent phenotype maturation. It appears that the microenvironment of the peptide is a critical determinant of its effect as immobilized YIGSR does mimic the effects of laminin matrix on ASM in vitro. Our data suggest that topically applied YIGSR mimics rather than inhibits the effects of laminin in vivo, and its use is linked to increased allergen-induced fibrosis, submucosal eosinophilia, ASM hyperplasia and airway hypercontractility. These data indicate that strategies to develop capacity to use peptides that target ECM-cell interaction to treat bronchial asthma need to be developed with care, in particular with focus on understanding differences of such interventions that may exist between in vitro and in vivo systems.

\section{Acknowledgements}

This work was financially supported by the Netherlands Asthma Foundation, grant NAF 3.2.03.36. We are grateful to Dr. W.T. Gerthoffer (University of Nevada-Reno) for preparation of the hTERT cell lines used in the study.

\section{Author details}

'Department of Molecular Pharmacology, University of Groningen, Groningen, Netherlands. 'Department of Physiology, University of Manitoba, Winnipeg, Manitoba, Canada.

\section{Authors' contributions}

BGJD: design of the study, acquisition of data, data analysis and interpretation, manuscript writing; ISTB: design of the study, acquisition of data, data analysis and interpretation; AJH: preparation of ASM cell lines and critical revision of the MS; JZ: design of the study, data interpretation and critical revision of the MS; HM: design of the study, data interpretation and critical revision of the MS. All authors have read and approved the manuscript.

\section{Competing interests}

The authors declare that they have no competing interests.

Received: 27 July 2010 Accepted: 3 December 2010

Published: 3 December 2010

\section{References}

1. Bousquet J, Jeffery PK, Busse WW, Johnson M, Vignola AM: Asthma. From bronchoconstriction to airways inflammation and remodeling. Am J Respir Crit Care Med 2000, 161:1720-1745.

2. Cockcroft DW, Davis BE: Mechanisms of airway hyperresponsiveness. J Allergy Clin Immunol 2006, 118:551-559.

3. Davies DE, Wicks J, Powell RM, Puddicombe SM, Holgate ST: Airway remodeling in asthma: new insights. J Allergy Clin Immunol 2003, 111:215-225.

4. Dunnill MS, Massarella GR, Anderson JA: A comparison of the quantitative anatomy of the bronchi in normal subjects, in status asthmaticus, in chronic bronchitis, and in emphysema. Thorax 1969, 24:176-179.

5. Parameswaran K, Willems-Widyastuti A, Alagappan VK, Radford K, Kranenburg AR, Sharma HS: Role of extracellular matrix and its regulators in human airway smooth muscle biology. Cell Biochem Biophys 2006, 44:139-146.

6. Fernandes DJ, Bonacci JV, Stewart AG: Extracellular matrix, integrins, and mesenchymal cell function in the airways. Curr Drug Targets 2006, 7:567-577.

7. Dekkers BG, Maarsingh $H$, Meurs $H$, Gosens R: Airway structural components drive airway smooth muscle remodeling in asthma. Proc Am Thorac Soc 2009, 6:683-692.

8. Halayko AJ, Salari H, Ma X, Stephens NL: Markers of airway smooth muscle cell phenotype. Am J Physiol 1996, 270:L1040-L1051.

9. Halayko AJ, Tran T, Ji SY, Yamasaki A, Gosens R: Airway smooth muscle phenotype and function: interactions with current asthma therapies. Curr Drug Targets 2006, 7:525-540.

10. Gosens R, Meurs H, Bromhaar MM, McKay S, Nelemans SA, Zaagsma J: Functional characterization of serum- and growth factor-induced phenotypic changes in intact bovine tracheal smooth muscle. $\mathrm{Br} J$ Pharmacol 2002, 137:459-466. 
11. Dekkers BG, Schaafsma D, Nelemans SA, Zaagsma J, Meurs H: Extracellular matrix proteins differentially regulate airway smooth muscle phenotype and function. Am J Physiol Lung Cell Mol Physiol 2007, 292:L1405-L1413.

12. Gosens R, Roscioni SS, Dekkers BG, Pera T, Schmidt M, Schaafsma D, Zaagsma J, Meurs H: Pharmacology of airway smooth muscle proliferation. Eur J Pharmacol 2008, 585:385-397.

13. Schaafsma D, McNeill KD, Stelmack GL, Gosens R, Baarsma HA, Dekkers BG, Frohwerk E, Penninks JM, Sharma P, Ens KM, et al: Insulin increases the expression of contractile phenotypic markers in airway smooth muscle. Am J Physiol Cell Physiol 2007, 293:C429-C439.

14. Tran T, McNeill KD, Gerthoffer WT, Unruh H, Halayko AJ: Endogenous laminin is required for human airway smooth muscle cell maturation. Respir Res 2006, 7:117.

15. Dekkers BG, Schaafsma D, Tran T, Zaagsma J, Meurs H: Insulin-induced Laminin Expression Promotes a Hypercontractile Airway Smooth Muscle Phenotype. Am J Respir Cell Mol Biol 2009, 41:494-504.

16. Nguyen NM, Senior RM: Laminin isoforms and lung development: all isoforms are not equal. Dev Biol 2006, 294:271-279.

17. Virtanen I, Laitinen A, Tani T, Paakko P, Laitinen LA, Burgeson RE, Lehto VP: Differential expression of laminins and their integrin receptors in developing and adult human lung. Am J Respir Cell Mol Biol 1996, 15:184-196.

18. Altraja A, Laitinen A, Virtanen I, Kampe M, Simonsson BG, Karlsson SE, Hakansson L, Venge P, Sillastu H, Laitinen LA: Expression of laminins in the airways in various types of asthmatic patients: a morphometric study. Am J Respir Cell Mol Biol 1996, 15:482-488.

19. Amin K, Janson C, Seveus L, Miyazaki K, Virtanen I, Venge P: Uncoordinated production of Laminin-5 chains in airways epithelium of allergic asthmatics. Respir Res 2005, 6:110.

20. Schuger L, Skubitz AP, Zhang J, Sorokin L, He L: Laminin alpha1 chain synthesis in the mouse developing lung: requirement for epithelialmesenchymal contact and possible role in bronchial smooth muscle development. J Cell Biol 1997, 139:553-562.

21. Relan NK, Yang Y, Beqaj S, Miner JH, Schuger L: Cell elongation induces laminin alpha2 chain expression in mouse embryonic mesenchymal cells: role in visceral myogenesis. J Cell Biol 1999, 147:1341-1350.

22. Hirst SJ, Twort CH, Lee TH: Differential effects of extracellular matrix proteins on human airway smooth muscle cell proliferation and phenotype. Am J Respir Cell Mol Biol 2000, 23:335-344.

23. Dekkers BG, Bos IS, Gosens R, Halayko AJ, Zaagsma J, Meurs H: The Integrin-blocking Peptide RGDS Inhibits Airway Smooth Muscle Remodeling in a Guinea Pig Model of Allergic Asthma. Am J Respir Crit Care Med 2010, 181:556-565.

24. Plow EF, Haas TA, Zhang L, Loftus J, Smith JW: Ligand binding to integrins. J Biol Chem 2000, 275:21785-21788.

25. Aumailley M, Gerl M, Sonnenberg A, Deutzmann R, Timpl R: Identification of the Arg-Gly-Asp sequence in laminin A chain as a latent cell-binding site being exposed in fragment P1. FEBS Lett 1990, 262:82-86.

26. Graf J, Ogle RC, Robey FA, Sasaki M, Martin GR, Yamada Y, Kleinman HK: A pentapeptide from the laminin B1 chain mediates cell adhesion and binds the 67,000 laminin receptor. Biochemistry 1987, 26:6896-6900.

27. Meurs H, Santing RE, Remie R, van der Mark TW, Westerhof FJ, Zuidhof AB, Bos IS, Zaagsma J: A guinea pig model of acute and chronic asthma using permanently instrumented and unrestrained animals. Nat Protoc 2006, 1:840-847.

28. Bos IS, Gosens R, Zuidhof AB, Schaafsma D, Halayko AJ, Meurs $H_{\text {, }}$ Zaagsma J: Inhibition of allergen-induced airway remodelling by tiotropium and budesonide: a comparison. Eur Respir J 2007, 30:653-661

29. Gosens R, Bos IS, Zaagsma J, Meurs H: Protective effects of tiotropium bromide in the progression of airway smooth muscle remodeling. Am $J$ Respir Crit Care Med 2005, 171:1096-1102.

30. Gosens R, Stelmack GL, Dueck G, McNeill KD, Yamasaki A, Gerthoffer WT, Unruh H, Gounni AS, Zaagsma J, Halayko AJ: Role of caveolin-1 in p42/p44 MAP kinase activation and proliferation of human airway smooth muscle. Am J Physiol Lung Cell Mol Physiol 2006, 291:L523-L534.

31. Gosens R, Dueck G, Gerthoffer WT, Unruh H, Zaagsma J, Meurs H, Halayko AJ: p42/p44 MAP kinase activation is localized to caveolae-free membrane domains in airway smooth muscle. Am J Physiol Lung Cell Mol Physiol 2007, 292:L1163-L1172.

32. Gosens R, Dueck G, Rector E, Nunes RO, Gerthoffer WT, Unruh H, Zaagsma J, Meurs H, Halayko AJ: Cooperative regulation of GSK-3 by muscarinic and PDGF receptors is associated with airway myocyte proliferation. Am J Physiol Lung Cell Mol Physiol 2007, 293:L1348-L1358.

33. Jeffery PK: Remodeling in asthma and chronic obstructive lung disease. Am J Respir Crit Care Med 2001, 164:S28-S38.

34. Postma DS, Timens W: Remodeling in asthma and chronic obstructive pulmonary disease. Proc Am Thorac Soc 2006, 3:434-439.

35. Graf J, Iwamoto Y, Sasaki M, Martin GR, Kleinman HK, Robey FA, Yamada Y Identification of an amino acid sequence in laminin mediating cell attachment, chemotaxis, and receptor binding. Cell 1987, 48:989-996.

36. Grant DS, Tashiro K, Segui-Real B, Yamada Y, Martin GR, Kleinman HK: Two different laminin domains mediate the differentiation of human endothelial cells into capillary-like structures in vitro. Cell 1989, 58:933-943.

37. Ebina M, Takahashi T, Chiba T, Motomiya M: Cellular hypertrophy and hyperplasia of airway smooth muscles underlying bronchial asthma. A 3-D morphometric study. Am Rev Respir Dis 1993, 148:720-726.

38. Woodruff PG, Dolganov GM, Ferrando RE, Donnelly S, Hays SR, Solberg OD, Carter R, Wong HH, Cadbury PS, Fahy JV: Hyperplasia of smooth muscle in mild to moderate asthma without changes in cell size or gene expression. Am J Respir Crit Care Med 2004, 169:1001-1006.

39. Benayoun L, Druilhe A, Dombret MC, Aubier M, Pretolani M: Airway structural alterations selectively associated with severe asthma. Am J Respir Crit Care Med 2003, 167:1360-1368.

40. Lambert RK, Wiggs BR, Kuwano K, Hogg JC, Pare PD: Functional significance of increased airway smooth muscle in asthma and COPD. J Appl Physiol 1993, 74:2771-2781

41. Oliver MN, Fabry B, Marinkovic A, Mijailovich SM, Butler JP, Fredberg J: Airway hyperresponsiveness, remodeling, and smooth muscle mass: right answer, wrong reason? Am J Respir Cell Mol Biol 2007, 37:264-272.

42. Matter ML, Laurie GW: A novel laminin E8 cell adhesion site required for lung alveolar formation in vitro. J Cell Biol 1994, 124:1083-1090.

43. Nelson J, McFerran NV, Pivato G, Chambers E, Doherty C, Steele D, Timson DJ: The $67 \mathrm{kDa}$ laminin receptor: structure, function and role in disease. Biosci Rep 2008, 28:33-48.

44. Miyamoto S, Akiyama SK, Yamada KM: Synergistic roles for receptor occupancy and aggregation in integrin transmembrane function. Science 1995, 267:883-885

45. Barthel SR, Johansson MW, McNamee DM, Mosher DF: Roles of integrin activation in eosinophil function and the eosinophilic inflammation of asthma. J Leukoc Biol 2008, 83:1-12.

46. Georas SN, Mclntyre BW, Ebisawa M, Bednarczyk JL, Sterbinsky SA, Schleimer RP, Bochner BS: Expression of a functional laminin receptor (alpha 6 beta 1, very late activation antigen-6) on human eosinophils. Blood 1993, 82:2872-2879.

doi:10.1186/1465-9921-11-170

Cite this article as: Dekkers et al:: The laminin $\beta 1$-competing peptide YIGSR induces a hypercontractile, hypoproliferative airway smooth muscle phenotype in an animal model of allergic asthma. Respiratory Research 2010 11:170

\section{Submit your next manuscript to BioMed Central and take full advantage of:}

- Convenient online submission

- Thorough peer review

- No space constraints or color figure charges

- Immediate publication on acceptance

- Inclusion in PubMed, CAS, Scopus and Google Scholar

- Research which is freely available for redistribution

Submit your manuscript at www biomedcentral com/submit
C Biomed Central 